\title{
INVESTIGATION OF THE CONSTITUENT FATTY ACIDS OF SOME FRESHWATER FISHES COMMON IN NIGERIA
}

\author{
UGOALA, C. ; NDUKWE, G. ${ }^{1}$ \& AUDU, T. ${ }^{1}$ \\ National Institute for Freshwater Fisheries Research, P.M.B. 6006, New Bussa, Niger State. \\ *Corresponding Author: nnaemekaugoala@yahoo.co.uk
}

1Department of Chemistry, Ahmadu Bello University, P.M.B. 1031, Zaria, Kaduna State, Nigeria

\begin{abstract}
Ugoala, C.; Ndukwe, G. \& Audu, T. 2009. Investigation of the constituent fatty acids of some freshwater fishes common in Nigeria. Braz. J. Aquat. Sci. Technol. 13(1):65-70. ISSN 1808-7035. The aim of this paper was to investigate the constituent fatty acids of some freshwater fish species as well as compare the nutritional quality of freshwater fish with that of marine fish by comparing the levels of essential fatty acids present. The fatty acids profile of freshwater fish species include minor amounts of odd-number, branched-chain, and even-number fatty acids as well as saturated components, the monounsaturated fatty acids and polyunsaturated fatty acids. The major saturated fatty acids were $\mathrm{C} 14: 0$ and $\mathrm{C} 16: 0$. The $\mathrm{C} 18: 1$ is the prominent monounsaturated fatty acids while the $\mathrm{C} 18: 2$ is the dominant polyunsaturated fatty acids. The essential fatty acids compositions showed prominence in C18:3n-3 and C18:2n-6. The overall significance of this study had been its revelation that freshwater fish are good source of omega- 6 essential fatty acids. The high percent of saturated fatty acids in freshwater fish gives them an advantage in curing processing.
\end{abstract}

Keywords: Fatty acids composition, Freshwater fish, Marine fish, nutritional quality, Fatty acids methyl ester.

\section{INTRODUCTION}

There is an inter and intra species variability in the composition of fatty acids of fish lipids (and of the specific polyunsaturated fatty acids in particular). This could be explained by the existence of a large number of external and internal factors. The external factors are environment, culturing method, and tropic effects. The internal factors include fish species, feeding regime and digestion, life cycle stage, quantitative and qualitative characteristics of lipids- triacyglycerols, phospholipids and their topographical origin- dorsal and ventral part of muscle tissue (Buchtova et al., 2004).

In recent years, there have been a large number of experimental studies into some of the above factors causing changes in the composition of fatty acids in various fish species (Csengeri et al, 1978; Farkas et al, 1978; Vanderwesthuyzen et al, 1984; Suzuki et al, 1986; Viola et al, 1988; Bieniarz et al, 2000). Other authors have studied the impact that various types of heat treatment will have on the fatty acids composition (Gall et al, 1983; Maeda et al, 1985; Tothmarkus and Sasskiss, 1993; Fajmonova et al, 2003).

Detailed information about lipid components and their fatty acids constituents is needed to understand how to diminish oxidative or hydrolytic factors which affect quality of fish. The nature, proportion, and degree of unsaturation of the fatty acids in the lipids are all closely related to the oxidation of the oils. However, the fatty acids composition of the muscle cell membranes are especially important factors in determining the stability because oxidative changes are initiated from the membrane components of muscle (Buckley et al, 1989). Rancidity development is a vital concern to the food industry because It may result in sensory changes (flavour and aroma), loss of nutritional value (Essential fatty acids, fat-soluble vitamins: $A, D, E, K$ ), production of primary and secondary oxidation products (hydro peroxides, free radicals, epoxides, etc). It can also be used for indexing, assisting in technology development.

Fatty acids profile analysis also provide information about the essential fatty acids requirements of fish which would aid the compounding of adequate protein-to-fat ratios feed that would balance energy requirements with caloric intake.

The aim of the study reported here was to investigate the fatty acids constituents of some freshwater fish species present in a Nigerian Lake by determining the amounts of saturated, monounsaturated, and polyunsaturated $n-3$ and n- 6 fatty acids.

\section{MATERIALS AND METHODS}

\section{Sample Collection and Preparation}

Fresh captured fishes were sorted and identified. They include Mormyridae (Hyperopisus bebe, Mormyrops anguilloides and Mormyrus rume), Cichlidae 
(Oreochromis niloticus and Sarotherodon galilaeus), Claridae (Clarias gariepinus and Clarias anguillaris), and Heterobranchus bidorsalis, Centropomidae (Lates niloticus), Clariheterobranchus (a hybrid of Clarias spp and Heterobranchus spp) and Characidae (Hydrocynus forskalii) were obtained from Fishermen at the Kainji Lake Dam site. The fishes were weighed, beheaded, eviscerated and cleaned prior to freezing. In an attempt to obtain a homogeneous sample from each species, their fleshes were removed from their backbones, minced, blended and immediately extracted using chloroform-methanol mixture in the ratio of 2:1.

\section{Lipid Extraction}

Lipid extractions were carried out on minced fish samples (10 $\mathrm{g}$ each) using the extraction methods of Folch et al (1957). In this method, chloroform-methanol was used in the ratio of $2: 1$. A total of three repetitions were performed per sample. The solvent mixtures were concentrated in vaccuo using a rotary evaporator maintained at $35^{\circ} \mathrm{C}$ and the extracts were stored in sample vial respectively.

\section{Fatty Acids Analysis}

The method of Park \& Goins (1994) was used in the methylation of the extracted fish lipids. Methylene chloride (100 iL) and $1 \mathrm{~mL} 0.5 \mathrm{M} \mathrm{NaOH}$ in methanol were added to oil extract in a test-tube and heated in a water bath at $90^{\circ} \mathrm{C}$ for $10 \mathrm{~min}$. The test tube was removed from the water bath and allowed to cool before the addition of $1 \mathrm{~mL} 14 \% \mathrm{BF}_{3}$ in methanol. The test tube was heated again in a water bath for $90^{\circ} \mathrm{C}$ for $10 \mathrm{~min}$, and cooled to room temperature. One $\mathrm{mL}$ of distilled water and $200 \mathrm{iL}$ hexane was added to the test tube respectively and then fatty acid methyl ester was extracted by vigorous shaking for one minute. After centrifugation, the top layer which contains the fatty acids methyl ester was collected and transferred into a sample vial for analysis. The fatty acids profiles were determined using an Agilent Gas Chromatograph, Model $6890 \mathrm{~N}$ fitted with an Agilent Mass Selective Detector, 5973 series. Separation was carried out in a capillary column (30 x $0.25 \mathrm{~mm}$ id $\times 0.25 \mathrm{im}$ DB wax). The starting temperature was $150^{\circ} \mathrm{C}$ maintained for 2 minutes at a heating rate of $10^{\circ} \mathrm{C} /$ minute. The total running time was 22 minutes. Helium was the carrier gas while the injection volume was 1ìL.

\section{RESULTS AND DISCUSSION}

Hyperopisus bebe, Mormyrops anguilloides, Mormyrus rume, Oreochromis niloticus, Sarotherodon galilaeus, Clarias gariepinus, Clarias anguillaris, Heterobranchus bidorsalis, Lates niloticus,
Clariheterobranchus, and Hydrocynus forskali are commercially important to freshwater fisheries in Nigeria, and they constitute a major part of landing, aquaculture and sources of animal protein. The fatty acids compositions of these fishes vary greatly. Therefore, a substantial normal variation is observed (Table 1) for the fatty acids constituent of these fishes as well as those of marine origin (Table 2) and their degree of unsaturation (Table 3). The fatty acids profiles include minor amounts of odd-number, branched-chain, and even-number fatty acids. These varieties as well as the quantity and quality of fatty acids noticed may be due to differences in subspecies, diet, spawning cycle, season and environment. The degree of unsaturation of fish oils vary with seasons. It rises as the water temperature falls and vice versa (IFFO BULLETIN No.18).

The knowledge of fatty acids composition of fishery species has fundamental importance in the application of different technological processes in fish preservation, processing and product development.

Clarias anguillaris and the tilapia species seem to be the most saturated fishes among the freshwater species (Table 3 ). The major saturated fatty acids identified in these species were $\mathrm{C} 14: 0$ and $\mathrm{C} 16: 0$. This high proportion of saturated fatty acids in these species could accounts for low iodine value in their oils. However, substantial amount of C18:2n-6 and C18:1 (Table 3) could also necessitate high iodine value. High iodine value shows the level of unsaturation in the fish oil. C18:1 and C18:2n- 6 presence may encourage lower melting point. C18:2n-6 and C18:3n-3 content among other factors (viscosity, colour, iodine value and peroxide value) determine oil quality for industrial purposes. Saturated fatty acids and cholesterol are major dietary contributors to coronary heart disease, due to their oxidation in the presence of light and molecular oxygen through a free radical reaction (Diplock, 1993). The branched chain fatty acids contents in the freshwater species studied were generally low especially in Hyperopisus bebe. Branched chain fatty acid has an important advantage. Branched chain fatty acids influence lower melting point, lower cholesterol levels, provide energy, influence some ribosomal functions which are necessary for peptide elongation and form an integral part of biomembranes while those esterified with cholesterol stimulate protein synthesis. (Hradec et al, 1974).

Fatty acids composition is also important as an aspect of quality of raw material, sensory attributes and storage stability. Hyperopisus bebe and Mormyrus rume content of the monoene fatty acids is about ninety percent with $\mathrm{C} 18: 1$ the prominent monounsaturated fatty acids. Polyunsaturated fatty acids attained the highest value $(90 \%)$ in Hydrocynus forskali. High contents of polyunsaturated fatty acids in Lates niloticus, Mormyrops anguilloides, Hydrocynus forskalii and 
Table 1. Fatty acids profile of freshwater fish.

\begin{tabular}{|c|c|c|c|c|c|c|c|c|c|c|c|}
\hline 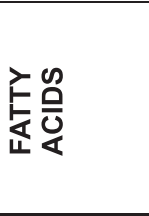 & 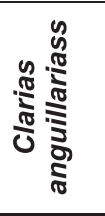 & 号 & 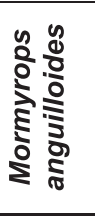 & 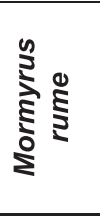 & 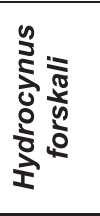 & 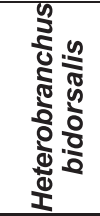 & 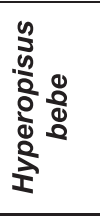 & 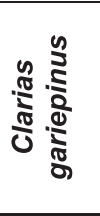 & 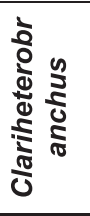 & 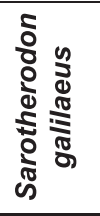 & 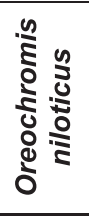 \\
\hline 12:0 & 11.20 & & 5.23 & 4.58 & & 19.89 & 3.58 & & 9.79 & & \\
\hline 13:0 & 3.43 & & & 0.98 & & 4.30 & 0.65 & & & & \\
\hline 14:0 & 7.99 & & & & & 14.52 & & 31.61 & & 3.81 & 17.82 \\
\hline $14: 1$ & 19.63 & & & & & & & 1.23 & & & \\
\hline 15:0 & 4.79 & & & 4.58 & & 9.14 & 3.58 & 5.43 & & 5.08 & 4.53 \\
\hline $15: 1$ & 2.74 & & & 1.96 & & 8.60 & 0.65 & 27.90 & 2.25 & & \\
\hline $16: 0$ & & 2.15 & & & & & & & & 36.38 & 34.14 \\
\hline 16:1 & & & & & & & & & & 10.15 & 12.39 \\
\hline $17: 0$ & & & & & & & & & & 4.65 & 1.81 \\
\hline $17: 1$ & & 0.92 & & & & & & & & & \\
\hline 18:0 & 2.05 & 3.38 & & & & & & 3.46 & & 9.31 & 5.74 \\
\hline $18: 1$ & & & & & & & & & & 12.27 & 9.37 \\
\hline $18: 1 \mathrm{cis}$ & & 4.92 & & & & & & 2.22 & & & \\
\hline 18:1trans & 4.11 & 4.31 & & & & & & 15.56 & & & \\
\hline $18: 2 n-6$ & & & & & & & & & & 4.65 & 3.02 \\
\hline $18: 3 n-3$ & & 6.15 & 1.31 & & & 6.18 & 0.98 & 2.22 & & 2.12 & 3.63 \\
\hline $18: 2 \mathrm{cis}$ & & 22.15 & 14.05 & & & 4.57 & & & & & \\
\hline 18:2trans & & 3.38 & 1.31 & & & & 0.33 & 1.98 & 19.26 & & \\
\hline $18: 3 n-6$ & & 5.85 & 12.09 & & & & & 4.94 & & & \\
\hline $18: 4$ & & & & & & & & & & 2.12 & 1.51 \\
\hline $20: 0$ & & 3.08 & 6.54 & & & & & & 13.16 & & \\
\hline $20: 1 n-9$ & & 4.31 & 13.73 & & & & & & 7.38 & & \\
\hline $20: 2$ & & 3.69 & 5.23 & & & & & & 12.68 & & \\
\hline $20: 3 n-6$ & & 7.07 & 4.25 & & & & & 1.48 & 4.17 & & \\
\hline $20: 3 n-3$ & & 2.78 & 4.25 & & & 4.30 & & & & & \\
\hline $20: 4 n-6$ & & 3.69 & 9.48 & & & & & 1.98 & 3.85 & 2.96 & 1.51 \\
\hline $20: 5 n-3$ & & 3.69 & 3.27 & & & & & & & 0.17 & 0.60 \\
\hline 21:0 & & 10.46 & 7.52 & & & & & & 3.85 & & \\
\hline $21: 1 n-11$ & & & 2.61 & & & 13.98 & & & & & \\
\hline 22:0 & 36.53 & & & & & & & & & & \\
\hline 22:1n-11 & & & & 86.27 & & & 89.25 & & & & \\
\hline $22: 2$ & & 6.46 & 0.65 & & 89.57 & 12.09 & & & & & \\
\hline $22: 5 n-3$ & & & & & & & & & & 2.54 & 1.51 \\
\hline $22: 6 n-3$ & & & & & & & & & & 3.81 & 2.42 \\
\hline 23:0 & 2.51 & & 1.31 & & 10.43 & & & & & & \\
\hline 24:0 & & 1.54 & & & & & & & & & \\
\hline
\end{tabular}

Clariheterobranchus (Table 3) and in the marine species, explains why they have very short keeping quality. They are very easily deteriorated if not well preserved. These fishes may not therefore be suitable for preservation through smoking, frying and sun drying except if antioxidants are used. Large or large oily fish require longer periods of processing, therefore cold smoking technique $\left(45-60^{\circ} \mathrm{C}\right)$ could be recommended for such fish species.

The presence of high levels of polyunsaturated fatty acids also means that when oils from these species are heated above $150^{\circ} \mathrm{C}$, formation of dimers and trimers as well as ring compounds could happen, while high amount of hydrogen are required for hydrogenation.

In all the fish species analysed, the dominant polyunsaturated fatty acids are of the Omega- 6 series and are found chiefly in C18:2 fatty acids. The essential fatty acids compositions showed prominence in C18:3n3 and C18:2n-6. C22:6n-3 was noted in the tilapia species.

Clarias anguillaris, Mormyrus rume, Hydrocynus forskali and Clariheterobranchus have undetectable levels of Omega- 3 fatty acids. Omega- 6 fatty acids were not detected in Clarias anguillaris, Mormyrus rume, Hydrocynus forskali, Heterobranchus bidorsalis, and Hyperopisus bebe. The essential fatty acids were lacking in Clarias anguillaris, Mormyrus rume, and Hydrocynus forskali. C22:6n-3 were absent in all the species except the tilapias. The tilapia species contain all the essential fatty acids although they vary in composition. C18:2n-6 contents in Lates niloticus and Clariheterobranchus as well as Mormyrops anguilloides are high in that order. The oils were characterized by low levels of Omega-3 polyunsaturated fatty acids. Fish oils rich in C18:2n-6 is essential in human nutrition 
Table 2: Fatty acids compositions of some marine fish species. Values courtesy of IFFO Fish oil bulletin no. 18.

\begin{tabular}{|c|c|c|c|c|c|c|c|c|c|c|}
\hline 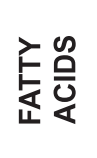 & 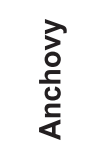 & 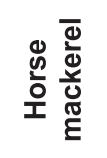 & 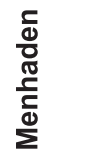 & 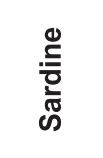 & 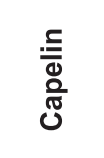 & 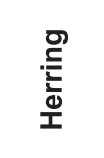 & 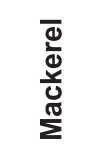 & 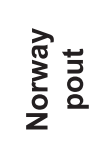 & $\begin{array}{l}\bar{\Xi} \\
\Phi \\
\overline{0} \\
\bar{్} \\
\infty\end{array}$ & $\begin{array}{l}\frac{\vec{\pi}}{0} \\
\text { के }\end{array}$ \\
\hline $14: 0$ & 8.48 & 7.95 & 8.95 & 5.68 & 6.53 & 8.50 & 7.80 & 5.57 & & \\
\hline $14: 1$ & & 0.55 & 0.30 & & & & & & & \\
\hline 15:0 & 0.73 & 16.70 & 0.65 & & & & & & & \\
\hline 16:0 & 19.43 & 7.35 & 19.10 & 17.80 & 10.23 & 14.27 & 16.10 & 12.30 & 14.63 & 16.50 \\
\hline $16: 1$ & 8.85 & & 11.50 & 6.80 & 9.30 & 6.13 & 9.00 & 4.70 & 7.03 & 6.80 \\
\hline 16:2 & & & 1.65 & & & & & & & \\
\hline $16: 3$ & & 1.40 & 1.90 & & & & & & & \\
\hline $16: 4$ & & 1.65 & 1.10 & & & & & & & \\
\hline 17:0 & 0.93 & 0.60 & 0.90 & & & & & & & \\
\hline 18:0 & 4.45 & 3.05 & 3.45 & 3.09 & 1.30 & 1.03 & 1.80 & 2.70 & 1.80 & 2.17 \\
\hline $18: 1$ & 14.20 & 9.30 & 10.00 & 7.85 & 14.03 & 9.67 & 12.90 & 13.90 & 9.05 & 15.67 \\
\hline 18:2 & 1.78 & 1.15 & 1.25 & 2.58 & 1.23 & 1.37 & 1.30 & 1.23 & 7.23 & 1.97 \\
\hline $18: 3$ & 0.68 & 0.60 & 1.35 & 1.87 & 0.60 & 1.50 & 1.10 & 1.17 & 5.68 & 1.73 \\
\hline $18: 4$ & & 1.90 & 2.70 & & 5.33 & 3.00 & 2.50 & 4.30 & & \\
\hline 20:0 & & 0.35 & & 0.63 & & & & & & \\
\hline $20: 1$ & 3.70 & 5.55 & 0.90 & & 12.67 & 12.60 & 12.10 & 10.23 & 15.08 & 10.27 \\
\hline 20:2 & & & & & 0.40 & 0.57 & 0.20 & 0.60 & & \\
\hline $20: 3$ & & 0.30 & & & & 0.40 & & & & \\
\hline $20: 4$ & 0.70 & 0.85 & 2.25 & & 1.67 & 5.10 & & 2.57 & & \\
\hline $20: 5$ & 16.23 & 13.65 & 14.10 & 8.43 & 9.97 & & 7.60 & 8.23 & 9.05 & 6.33 \\
\hline $21: 5$ & & 0.35 & 0.65 & & & & & & & \\
\hline 22:0 & & 0.20 & & & & & & & & \\
\hline 22:1 & 1.85 & 9.55 & 0.30 & 5.07 & 10.63 & 21.83 & 13.90 & 11.70 & 15.53 & 14.10 \\
\hline 22:2 & & & & & 0.60 & 0.37 & & 0.60 & & \\
\hline 22:4 & & & & & & & & & & 0.67 \\
\hline $22: 5$ & 0.98 & 2.00 & 2.45 & & 0.63 & 0.80 & 0.60 & 10.67 & 0.73 & 0.65 \\
\hline $22: 6$ & 9.55 & 9.35 & 8.55 & 15.53 & 9.57 & 6.47 & 7.70 & 14.33 & 8.90 & 8.73 \\
\hline
\end{tabular}

because of the presence of the fatty acids. These fatty acids are not synthesized by the body but are required for tissue development. Our result however, generally suggests that Wild freshwater fish has low Omega-3: Omega- 6 ratios (Table 3).

\section{Comparison of Freshwater Fish and Marine Fish}

The fatty acid composition of marine fish species (Table 2) have similar pattern. The freshwater species however, differs in their fatty acids compositions pattern. A study of Table 2 places the marine fish species into two groups. Group one include Anchovy, Horse mackerel, Menhaden and Sardine while Capelin, Herring, Mackerel, Norway pout, Sand eel and Sprat make up group two. Group one are higher in saturated fatty acids, particularly C16:0, higher in polyunsaturated fatty acids (C20:5), lower in monounsaturated fatty acids (C20:1 and C22:1), similar in fatty acids composition, and may be more susceptible to oxidation compared with group two oils because of the higher level of unsaturation of the former.

Our results revealed that freshwater fish has more Omega- 6 series of the polyunsaturated fatty acids while the marine has more Omega-3 series (Tables 3 ). The prominent Omega-3 being C22:6 while the C18:2 are for the Omega- 6 series. This may suggest that the dietary essential fatty acids requirements for marine fish for Omega-3 polyunsaturated fatty acids may be higher than that of freshwater fish. It could also suggest that marine species are suppliers of C18:3n-3; the initial building blocks for all Omega-3 fatty acids in the human body although Clarias anguillaris, Lates niloticus, Heterobranchus bidorsalis, Clarias gariepinus, Clariheterobranchus, Oreochromis niloticus and Sarotherodon galilaeus compares favourably with marine in C18:3n-3. However, only Lates niloticus seems to compares well with marine species on $\mathrm{C} 20: 5 n-3$ content. The marine species are better in $C 22: 6 n-3$. The freshwater species are in C18:2n-6 as well as in C20:4n6 contents. The latter fatty acid is a major constituent of membrane lipids (phospholipids) and is the principal precursor by enzymatic action of hormone-like compounds known as eicosanoids including the prostaglandins (prostanoids, isoprostanes, and isofurans). The eicosanoids produced from C20:4n-6 cause the strongest inflammatory response in humans. Inflammation is one of the body defense mechanisms that reduce the spread of infection. 
Table 3. Major fatty acids found in freshwater fish. Nd-not detected, SFA-saturated fatty acid, MUFA-monounsaturated fatty acid, and PUFA-polyunsaturated fatty acid.

\begin{tabular}{|c|c|c|c|c|c|c|c|c|c|c|c|}
\hline 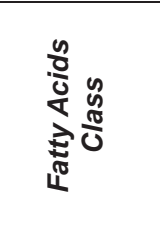 & : & 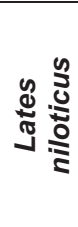 & 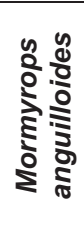 & 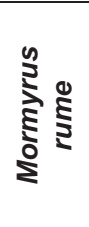 & 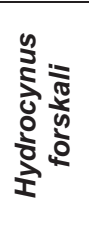 & 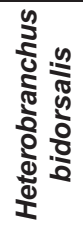 & 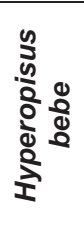 & $\frac{\substack{\frac{5}{2} \\
\frac{\pi}{2}}}{\frac{\pi}{0}}$ & 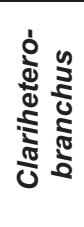 & 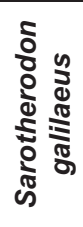 & 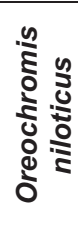 \\
\hline SFA & 73.51 & 20.63 & 33.00 & 11.77 & 10.43 & 50.28 & 8.79 & 40.49 & 50.41 & 59.21 & 64.04 \\
\hline MUFA & 26.48 & 14.46 & 16.34 & 88.23 & nd & 22.58 & 89.90 & 46.91 & 9.63 & 22.42 & 21.76 \\
\hline PUFA n-3 & nd & 12.62 & 8.83 & nd & nd & 10.48 & 0.98 & 2.22 & nd & 8.64 & 8.16 \\
\hline PUFA n-6 & nd & 16.61 & 25.82 & nd & nd & nd & nd & 8.40 & 8.02 & 7.61 & 4.53 \\
\hline PUFA total & nd & 64.91 & 50.66 & nd & 89.57 & 27.14 & 1.31 & 12.60 & 39.96 & 18.37 & 14.20 \\
\hline$n-3: n-6$ & & 0.76 & 0.34 & nd & nd & 10.48 & 0.98 & 0.26 & 0.00 & 1.14 & 1.80 \\
\hline BRANCHED & 4.79 & 34.76 & 15.36 & nd & nd & 4.57 & 0.33 & 19.76 & 19.26 & nd & nd \\
\hline
\end{tabular}

\section{CONCLUSION}

The paper investigated the constituent fatty acids of some freshwater fish species as well as compares the nutritional quality of freshwater fish with that of marine fish by comparing the levels of essential fatty acids present. The overall significance of this study had therefore been its revelation that marine fishes are better sources of omega-3 essential fatty acids while freshwater fish are good source of omega- 6 essential fatty acids. The regular pattern of marine fish fatty acids compositions makes them of advantage to the Hydrogenator. The high percent of saturated fatty acids in freshwater fish gives them an advantage in curing processing. The freshwater fish may have better oil quality than their marine counterparts because of the high content of 18:2n-6 and 20:4n-6 Fatty acids.

\section{REFERENCES}

Bieniarz K.; Koldras, M.; Kaminski, J. \& Mejza, T. 2000. Fatty Acids and cholesterol in some freshwater fish species in Poland. Folia Univ. Agric Stetin 27:2-44 Buckley, D.J;Gray,J.I; Ashar, A.; Price, J.F.; Crackle R.L.; Booren, A.M.; Pearson A.M. \& Miller E.R. 1989. Effects of dietary antioxidants and oxidized oil on membrane lipid stability and pork product quality. J. Food Sci. 54:1193-1197

Buchtova, H., Smutna, M., Vorlova, L., Svobodova, Z. \& Flajsans, M. 2004. Fatty Acid Composition of Diploid and Triploid populations of Trench (Tinca tinca L.). ACTA VET. BRNO 73:235-245

Csengeri, I.; Farkas, T.; Majoros, F.; Olah, J. \& Szalay, M. 1978. Effect of feeds on the FA composition of carp (Cyprinus carpio L). Aquacult. Hung 1:24-34
Cowey, C.B.; Owen, J.M.; Adron, J.W. \& Middleton, C. 1976. Studies on the nutrition of marine flatfish. The effect of different dietary FA on the growth and FA composition of turbot (Scophthalmus maximus). British J.Nutr 36:479-486

Deshimaru, O.; Kuroki, K. \& Yone, Y. 1982. Nutritive values of various oils for yellow. Bulletin Jpn. Soc. Sci. Fisheries 48:1155-1157

Fajmonova, E.; Zelenka, J.; Komprda, T.; Kladroba, D. \& Sarmanova, A. 2003. Effect of sex, growth intensity and heat treatment on FA composition of common carp (Cyprinus carpio) fillets. Czech J Anim Sci 48 suppl 2:85-92

Farkas, T.; Csengeri, I.; Majoros, F. \& Olah, J. 1978. Metabolis of FA in fish II. Biosynthesis of FA in relation to diet in the carp (Cyprinus carpio $\mathrm{L}$ ). Aquaculture 14:57-65

Folch, J.; Lees, M; \& Sloane Stanley, G.H. 1957. A simple method for the isolation and purification of total lipids from animal tissues. J. Biol. Chem. 226:497-509.

Gall, K.I.; Otwell, W.S.; Koburger, J.A. \& Appledorf, H. 1983. Effects of four cooking methods on the proximate, mineral and FA composition of fish fillets. J. Food Sci. 48:1068-1074

Hradec, J.; Dusek, Z. \& Mack, O. 1974. Biochem.J. 138,147

International Fish Oil And Fish Meal Organisation Fish Oil Bulletin. NO.18,Young,F.V.K.(Ed), Liverpool, UK Josephson, D.B. 1991. Seafood. In volatile compounds in food and Beverages, Maarse, H (Ed), p179-202. Marcel Dekker, Inc. New york.

Maeda, Y.; Ishikawa, M.; Yamamoto, M.; Terada, S.; Masui, T. \& Watanabe, Y. 1985. Effect of cooking on contents of FA, especially EPA and DHA in sardine. J. Jpn Soc Nutr Food Sci. 38:447-450 
Suzuki, H.; Okazaki, K.; Hayakawa, S.; Wadw, S. \& Tamura, S. 1986. Influence of commercial dietary FA on PUFA of cultured freshwater fish and comparison with those of wild fish of the same species. J.Agric. Food Chem 34:58-60

Takeuchi, T. \& Watanabe, T. 1977. Requirement of carp for Essential fatty acids. Bulletin Jpn. Soc. Sci. Fisheries 43:541-551

Tothmarkus, M. \& Sasskiss, A. 1993. Effect of cooking on the FA composition of silver carp (Hypophthalmichthys molitrix). Pol. Arch. Hydrobiol 42 suppl. 3:337-346
Viola, S.; Mokady, S.; Behar, D. \& Cogan, U. 1988. Effects of PUFA in feeds of tilapia and carp I.Body composition and FA profiles at different environmental temperatures. Aquaculture 75:127-137

Vanderwesthuyzen, J.; Chetty, N.; Gibbson, J.E.; Bradlow, B.A. 1984. Fatty Acids composition of a fish diet. S Afr J. Sci. 80:330-331

Submetido: Maio/2008 Revisado: Setembro/2008

Aceito: Outubro/2008 